\title{
Young Children Perception on Authoritarian Parenting
}

\author{
Beatriks N. Bunga ${ }^{1, *}$ Angelikus N. Koten ${ }^{1}$ Kristin Margiani ${ }^{1}$ Theodorina N. Seran ${ }^{1}$ \\ Indra Yohanes Kiling ${ }^{2}$
}

\author{
${ }^{1}$ Early Childhood Education Department, Unversity of Nusa Cendana, Kupang, Indonesia \\ ${ }^{2}$ Psychology Department, Unversity of Nusa Cendana, Kupang, Indonesia \\ *Corresponding author. Email: beatriks.bunga@staf.undana.ac.id
}

\begin{abstract}
One of the most common parenting practice found in Kupang city is harsh parenting. This type of parenting put less focus in understanding children's opinions, feelings and hopes and more in physical and verbal punishment such as spanking, yelling and slapping. This study aims to explore children's perception on their parents' parenting practice with three main objectives, what do their parents do when they do something wrong, what causes their parents to do that and what is their feelings and hopes for their parents. Participants in this study were recruited from 12 kindergartens in Kupang City. Data collection were done in two months using interview session on 26 boys (43\%) and 34 girls (56\%) aged five to six years old. Data were analyzed using thematic analysis. Results shown that there are three main reactions from parents when their children made mistake, that is physical punishment, verbal punishment, and permissive punishment. The antecedent of these responses identified are internal factors from the children (e.g. children refuses to eat or sleep) and external factors (e.g. parents under influence of alcohol, conflict between parents). Fathers, mothers and even other caregivers such as grandmothers are identified to be involved in harsh parenting. Children admitted several negative feelings such as feeling sad, alone, afraid and also often expressed their emotions in crying. There are six hopes from children for their parents, they long for physical contact, verbal expression, non verbal expression, spending time together, gifts and also sometimes they want nothing at all. Based on this study, parents in Kupang City could use more knowledge and skills to understand young children and how to discipline them without resorting to harsh parenting practices.
\end{abstract}

Keywords: Harsh parenting, parents, young children

\section{INTRODUCTION}

Parent have responsibilities to provide positive and loving parenting practices to support their children's development. Errors and mistakes in parenting could bring negative outcomes on children. Children's future largely depends on experience they receive in the present, including education and parenting practices their parents applied. Past studies discovered significant influence between parenting practices and children's behavior issues (Vinayastri, 2015; Suharsono, Fitriyani, \& Upoyo, 2009). Children raised with assertive and affective parenting practices correlates with competent social abilities and emotional control. These children are well-behaved in school, full of confidence and showing purpose in their daily activities (Baumrind, 1966; Ally, 2010; Suharsono et al., 2009). On the contrary, children raised with harsh parenting practices, filled with constant pressure, threats and punishment from parents showed different results. Harsh parenting is a parenting concept used globally by UNICEF (De Stone et al., 2016). It is indicated by parents routinely spanks, yells, and slaps their children when in anger (Jackson \& Choi, 2018; Skinner et al., 2014). Children exposed with harsh parenting do not develop social abilities that is comparable with children cared with democratic and permissive parenting style. These children showed poor capabilities in managing their frustration, specifically girls were more likely to succumb to challenges while boys were more likely to demonstrate aggressive behaviors. These children also vulnerable to low self-esteem, anxiety and depression (Baumrind, 1997). Parenting practices applied to children mostly are not the kind of practices that they prefer. Parents mostly just adopt parenting practices and style that fits with their beliefs, experience and knowledge. Children become passive objects of parenting. It is rare to find parents who discuss and evaluate their children's opinion and hope on what kind of parenting that they prefer. Most studies in the past put more emphasis in parents perspective (Vinayastri, 2015; Suharsono, 2009), where little has been done to explore how children see parenting practices and what is an ideal parenting according to their expectation.

This study aims to describe how young children perceive parenting practices that they experience, with more focus on harsh parenting practice. This study hopefully could give a broader viewin parenting study by providing children's perspective, particularly children raised in vulnerable areas. 


\section{METHODOLOGY}

\subsection{Participants}

Population in this study consisted of 102 kindergartens in Kupang City, East Nusa Tenggara province, Indonesia. Samples from this study were obtained with random sampling method, resulted in 12 kindergartens selected to participate in this study. Five children aged five to six years old were randomly selected from each school to participate. Children were approached in their school after getting permission from teachers and parents, they were asked to participate and also given options to refuse to participate. All children approached were willing to participate in the study. Total of 60 children that consisted of 26 boys ( $43 \%)$ and 34 girls (56\%) involved until the end of the study. 43 children were aged five years old, and 17 others were aged six years old.

\subsection{Data Collection and Analysis}

Data is collected using semi-structured interview session on each child with average duration of interviews between 10 to 15 minutes. Three main questions asked were: (1) what did your parents (or caregivers) do when you made a mistake? (2) how did you feel on that? And (3) what is your hope on your parents based on that? Interview sessions were conducted by authors with some help from undergraduate students.

Data were then transcribed and analyzed using thematic analysis approach. Each authors gave codes in these transcripts, that were then discussed by all authors. Through an interactive process between the authors, codes were further analyzed and extracted into sub-themes. After having undergone further analysis, five main themes were decided as the main findings of this study.

\section{FINDINGS \& RESULTS}

Thematic analysis of interview sessions data on children's perception on parenting resulted in five themes (see Figure 1): 1) parent reactions, 2) actors of harsh parenting, 3) Causes of harsh parenting, 4) child feelings, and 5) child expectation on their parents.

\subsection{Parent Reactions When Child Make Mistake}

This theme consisted of three sub-themes that detailed how parents reacted to their child's wrongdoing: a) physical punishment such as hitting and pinching. All interviewed children stated that the physical punishment that they often get is being hit by their parents. Body parts that is often been hit are hands, buttocks and back or chest; b) verbal aggression also one of the main reactions from parents, children often get yelled, scolded and even cursed; c) non-verbal reaction also reported by children. Parents expressed this reaction by slamming things around children and glared at children; d) children also reported permissive reaction which is when parents letting children by their mistakes without consequences. Figure 2 summed up parent reactions with samples of their original quotes in Bahasa Indonesia.

\subsection{Actor of Harsh Parenting}

Interview analysis showed that physical punishment, verbal and non-verbal aggression, and permissive reaction that children experience was done mainly by members of nuclear family such as father, mother, and siblings (both older and younger siblings). Extended family members also reported by children to be the actor of harsh parenting in their house (See Figure 3). It seems that it is common in these children's community when members of extended family of a household live in a house together with them, this resulted in the fact that some parenting practices were also carried out by these extended family members.

\subsection{Causes of Harsh Parenting on Children}

Children participated in the interview also reported their perceptions on causes of harsh parenting that were done by their parents or caregivers (see Figure 4): a) Internal factors such as when child refused to help their parents in doing chores and when they disobeying parent's order, and; b) external factors such as parents who are alcoholic and also have marital conflict that can trigger harsh parenting experienced by young children.

\subsection{Child Feelings}

Young children experience negative feelings such as feeling alone, lonely and also afraid when they get harsh parenting from their parents. These feelings mostly disappeared along with time, but some children also reported constant negative feelings especially when they are with their parents. They also express their feelings with several reactions such as crying and hiding behind chair and inside their room (see Figure 5).

\subsection{Child Expectation on Parents}

Children stated in interview sessions that they have five main expectation on their parents regarding parenting practices. Firstly, they prefer physical contact such as 
being hug when they make mistake, they also prefer their parents to play with them instead of being angry with them. Secondly they prefer better verbal expression from their parents like softer tone when correcting them of their mistakes and not yelling to them. They long for the way their parents say they love them instead of being cursed upon.

Thirdly they expect better non-verbal expression from their parents such as smiling, children prefer their parents to smile and not saying anything when they made mistakes. Fourthly, children expect their parents to provide more time to spent with them, preferably to travel and play together. Lastly, children really love when their parents give them presents that they like (Figure 6).

\section{DISCUSSION}

Qualitative investigations on young children proved to be effective in providing rare perspective particularly in subjects important to them such as parents (Kilicgun, 2016). This study utilized the inductive approach to discover young children's perspective on harsh parenting carried out by parents or caregivers. The research findings contrasted with previous survey research in Kupang City highlighting that harsh parenting were no longer the main parenting practices that fathers preferred (Tea, Thoomaszen, Kiling-Bunga, \& Kiling, 2016).

This fact is particularly significant and need more attention from policy makers and academics to be explored in the future. Exploration of such taboo subject like harsh parenting using qualitative approach like in this study might uncover some truth that is often overlooked in quantitative researches. Since the results are not conclusive with previous studies, it is highly suggested that more thorough and rigorous research is needed in the future.

This study also highlighted how fathers in Kupang City played significant part as actors of harsh parenting, opposed to Tea et al. (2016) study who stated that fathers in Kupang City were not accustomed to harsh parenting in raising their children. As most domestic violence were done by fathers, fathers are suggested to understand more about positive parenting practices and alcohol therapy to avoid constant harsh parenting that could lead to domestic violence cases (Flury \& Nyberg, 2010).

Practice of harsh parenting on young children could often be found not only in developing countries such as Indonesia like in this study, but also in developed countries such as the United States (Jackson, Choi, \& Preston, 2019). Similarities that could be identified from these studies are both study participants came from similar economical background, that is poor family. While past study in United States stated that family of black people were more likely to practice harsh parenting (Jackson et al., 2019), this study does not identify particular racial or other demographic characteristics that is more likely to conduct harsh parenting practices.
Finally, while previous studies put more focus on parental expectations especially on their children's education (Bush, Cohen, Eisenhower, \& Blacher,2017) this study underlines the importance of children expectation on their parents. It is suggested that more study is needed in order to fully discover what children expectation can do in building a healthy family relationship, particularly in relations with parenting practices.

This study has some limitations. Comprehensive point of view could be obtained if parents and teachers are also involved in the study. Due to limitations however, this study had not able to do so. Another limitation is that authors did not able to build proper rapport with the children, the effect of this has been minimized however, with the involvement of undergraduate students who were at the time were teaching in these children's kindergartens. In conclusion, the threat of harsh parenting in the society is real and action is needed to combat this in order to create a supportive environment for young children's development. Parents need to be made aware of the possibilities and benefits in positive parenting and academics should play their parts accordingly in order to support this objective by conducting more studies in a progressive manner.

\section{REFERENCES}

Ally. (2010). Diana Baumrind's 3 Parenting Styles: get Fulunderstanding of the 3 Archetypical Parents. Retriever from https://www.positive-parentingally.com/site-map.html

Baumrind, D. (1966). Effects of authoritative parental control on child behavior. Child Development, 37(4), 887-907.

Baumrind, D. (1997). The discipline encounter: Contemporary issues. Aggression and Violent Behavior, 2(4), 321-335.

Bush, H. H., Cohen, S. R., Eisenhower, A. S., \& Blacher, J. (2017). Parents' educational expectations for young children with autism spectrum disorder. Education and Training in Autism and Developmental Disabilities, 52(4), 357-368.

De Stone, S., Meinck, F., Sherr, L., Cluver, L., Doubt, J., Orkin, F. M., ... \& Redfern, A. (2016). Factors associated with good and harsh parenting of preadolescents and adolescents in Southern Africa. Florence: UNICEF.

Flury, M., \& Nyberg, E. (2010). Domestic violence against women: definitions, epidemiology, risk factors and consequences. Swiss Medical Weekly, 140(3536), $1-6$. 
Jackson, A. P., Choi, J. K., \& Preston, K. S. (2019).

Harsh Parenting and Black Boys' Behavior Problems:

Single Mothers' Parenting Stress and Nonresident

Fathers' Involvement. Family Relations, 68(4), 436-

449.

Jackson, A. P., \& Choi, J. (2018). Parenting stress, harsh parenting, and children's behavior. J Family Med Community Health, 5, 1150-1158.

Kilicgun, M. Y. (2016). Perception of parental love in 4-6 year-old children. European Proceedings of Social and Behavioral Sciences, 9, 68-77.

Skinner, A. T., Bacchini, D., Lansford, J. E., Godwin, J. W., Sorbring, E., Tapanya, S., ... \& Bombi, A. S. (2014). Neighborhood danger, parental monitoring, harsh parenting, and child aggression in nine countries. Societies, 4(1), 45-67.

Suharsono, J. T., Fitriyani, A., \& Upoyo, A. S. (2009). Hubungan pola asuh orang tua terhadap kemampuan sosialisasi pada anak prasekolah di TK Pertiwi Purwokerto Utara. Jurnal Keperawatan Soedirman, 4(3), 112-118.

Tea, M. E., Thoomaszen, F. W., Kiling-Bunga, B. N., \& Kiling, I. Y. (2016). Pola asuh keras pada ayah dari anak usia dini: studi deskriptif. Intuisi: Jurnal Psikologi Ilmiah, 8(1), 1-6.

Vinayastri, A. (2015). Pengaruh pola asuh (parenting) orang-tua terhadap perkembangan otak anak usia dini. Jurnal Ilmiah WIDYA, 1(1), 33-42. 